WSRC-TR-2001-00013

SRT-RPP-2001-00005

\title{
Characterization of a Washed 241-C-106 Sludge Sample
}

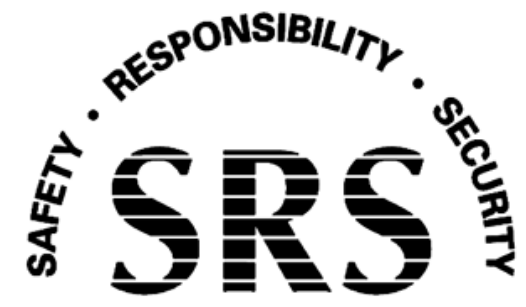


This document was prepared in conjunction with work accomplished under Contract No.

DE-AC09-96SR18500 with the U.S. Department of Energy.

\section{DISCLAIMER}

This report was prepared as an account of work sponsored by an agency of the United States Government. Neither the United States Government nor any agency thereof, nor any of their employees, makes any warranty, express or implied, or assumes any legal liability or responsibility for the accuracy, completeness, or usefulness of any information, apparatus, product or process disclosed, or represents that its use would not infringe privately owned rights. Reference herein to any specific commercial product, process or service by trade name, trademark, manufacturer, or otherwise does not necessarily constitute or imply its endorsement, recommendation, or favoring by the United States Government or any agency

thereof. The views and opinions of authors expressed herein do not necessarily state or reflect those of the United States Government or any agency thereof.

This report has been reproduced directly from the best available copy.

Available for sale to the public, in paper, from: U.S. Department of Commerce, National Technical Information Service, 5285 Port Royal Road, Springfield, VA 22161, phone: (800)

553-6847, fax: (703) 605-6900, email: orders@ntis.fedworld.gov online ordering: http://www.ntis.gov/ordering.htm

Available electronically at http://www.doe.gov/bridge

Available for a processing fee to U.S. Department of Energy and its contractors, in paper, from: U.S. Department of Energy, Office of Scientific and Technical Information, P.O. Box 62, Oak Ridge, TN 37831-0062, phone: (865 ) 576-8401, fax: (865) 576-5728, email: reports@ adonis.osti.gov 
WSRC-TR-2001-00013

SRT-RPP-2001-00005

KEYWORDS:

Hanford River Protection Project

Sludges

Characterization

Leaching

\section{Characterization of a Washed C-106 Sludge Sample}

SAVANNAH RIVER TECHNOLOGY CENTER

Charles A. Nash

Publication Date: January 2001

Westinghouse Savannah River Company

Savannah River Site

Aiken, SC 29808

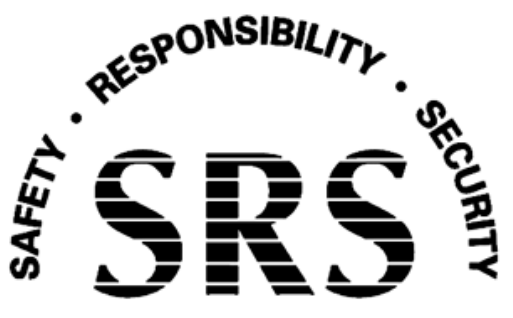

Prepared for the U.S. Department of Energy under Contract No. DE-AC09-96SR18500 
DOCUMENT:

TITLE:
WSRC-TR-2001-00013 (SRT-RPP-2001-00005)

Characterization of a Washed C-106 Sludge Sample

APPROVALS

Date:

Charles A. Nash, Author

Date:

RPP Pretreatment or Vitrification Manager

Date:

Charles L. Crawford, Technical Reviewer 


\section{Contents}

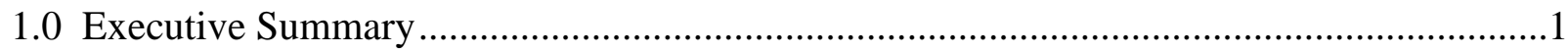

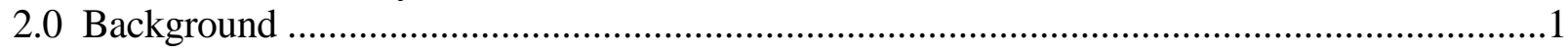

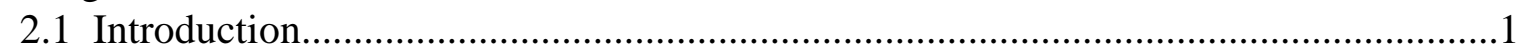

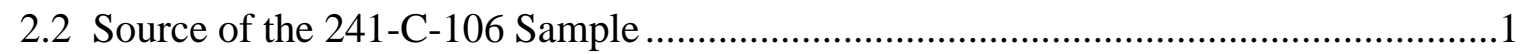

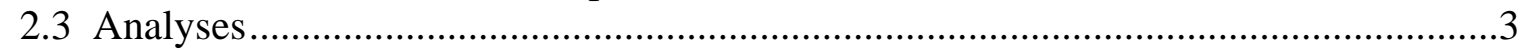

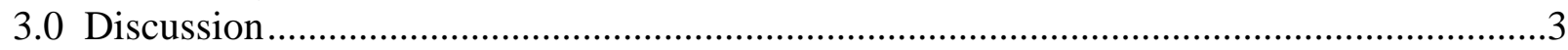

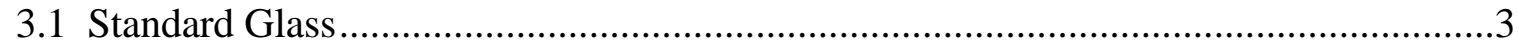

3.2 Initial Sample Compositing and Dilution...............................................................

3.3 Steps for Sample Analysis .................................................................................

3.4 Filtrate Compositions ............................................................................................

3.5 Solids Composition........................................................................................

3.6 Comparison of Solids Composition to Other Work ..................................................12

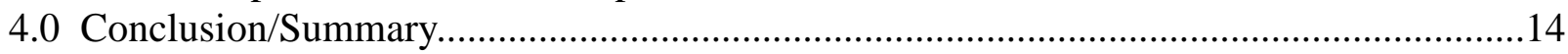

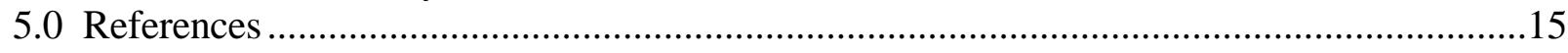

Appendix

\section{List of Figures}

Figure 1. Flowchart for the Samples from the Six Wt\% Measurements of Diluted D-2............6 Figure 2. C106 Sludge Solids - Past Works vs. Nash Elemental Wt\% .....................................13

\section{List of Tables}

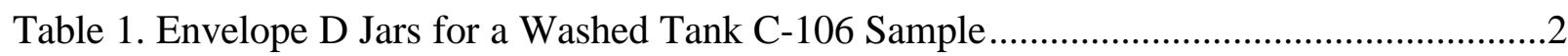

Table 2. List of Analytes...............................................................................................

Table 3. Standard Glass Composition - Elemental Weight Percent ............................................4

Table 4. Dilution and Weight Percents in the Composite.........................................................5

Table 5. Composition of the Filtrate from the As-received Composite - ICP-ES Metals ............7

Table 6. Composition of the Filtrate from the As-received Composite - Rad Chem, Metals .....8

Table 7. Composition of the Filtrate from the Diluted Composite ……………………...............9

Table 8 Composition of the Dried Solid Sludge ……………................................................ 10

Table 9. Radiochemical Composition of the Dried Solids by Acid Dissolution........................11

Table 10. Radiochemical Composition of the Dried Solids by Peroxide Fusion..........................12

Table 11. Tabular Data from Figure 2 .................................................................................13

Table 12. Comparison of Major Isotopic Levels with Brooks...................................................14 


\subsection{Executive Summary}

An Envelope D Tank 241-C-106 sample was characterized for solids, elemental, and radioactive isotope content. The work was done by the Savannah River Technology Center (SRTC) to support the Hanford River Protection Project (RPP). The sludge from Hanford Tank 241-C-106 is high level waste that is to be included in the first ten years of processing by the RPP Waste Treatment Plant (WTP). The sample was a composite of caustic-leached and washed sludge from previous work at the Pacific Northwest National Lab (PNNL). Sludge analysis results were found to compare well with those of previous researchers analyzing leached samples from Tank 241-C-106. Composition of the liquid accompanying the sample was also measured.

Dilution of the composited Tank 241-C-106 sample to $5 \mathrm{wt} \%$ insoluble solids dissolved additional sodium that was present in the as-received sample. This would be expected since it is similar to water washes of this sludge done in prior work. The washes were done at room temperature with the purpose being to remove sodium. The measurement of oxalate indicated that sodium oxalate was one of the components being dissolved out of the solid phase.

\subsection{Background}

\subsection{Introduction}

Hanford Waste Tank 241-C-106 was one of the first ten tanks chosen by the River Protection Project (RPP) for processing in the first ten years of waste stabilization. Tank 241-C-106 is a high heat single shell tank. The contents of Tank 241-C-106 were sluiced to another tank Tank 241-AY-102 supernate for staging to the RPP-WTP after the sample characterized here was taken.

It was not originally planned to send this sample to SRTC. SRTC had received a 241-AZ-102 Envelope $\mathrm{B} / \mathrm{D}$ sample for characterization and filtration testing. However, that sample was found to have little solids (52 grams or one quarter of the 200 grams of dried solids that were expected). ${ }^{1}$ The RPP customer advised SRTC that the 241-AZ-102 sample would not be used in further work outside of characterization. ${ }^{2}$ There were insufficient solids in the 241-AZ-102 sample for filtration and vitrification work that was planned. A suitable shipping cask was not available to ship a second 241-AZ-102 sample to SRTC.

The 241-C-106 sample was a substitute containing a larger quantity of solids. Some of the bottles that contained the Tank 241-C-106 sample no longer had a separate supernate layer that was visible. Plans were to use the solids from these sample bottles for filtration and vitrification studies.

The composited 241-C-106 sample was characterized per the SRTC characterization Task Plan, following the list of analytical methods for sludge. ${ }^{3}$ The task plan lists the quality assurance procedures governing the work. Steps taken in the Shielded Cells were recorded in a controlled laboratory notebook. ${ }^{4}$

\subsection{Source of the 241-C-106 Sample}

The Tank 241-C-106 sample was originally obtained during a Tank 241-C-106 June 1996 sampling event. $^{5,6}$ Urie provides details of the sample handling. ${ }^{7}$ The sample in this characterization report was composited of subsamples that had been stored at the Pacific NorthWest National Lab (PNNL) since June 
1996. They were archive samples that had been washed and leached by Brooks. ${ }^{8}$ Brooks and co-workers used a rig called The Sludge Pretreatment Demonstration (SPD) apparatus to perform two caustic leaches and three water washes of a 3 kilogram batch of C-106 sludge feed. The goal of the SPD was to remove sufficient amounts of aluminum, chromium, and phosphorus in order to reduce the total volume of high level waste as well as to improve the quality of glass that would otherwise be impacted by these elements.

The sludge in Brooks' work was twice leached with $3 \mathrm{M} \mathrm{NaOH}$ at $100^{\circ} \mathrm{C}$, and then extra sodium was washed out with three washes of water containing $0.01 \mathrm{M}$ of both sodium hydroxide and sodium nitrite (inhibited water). Settle/decanting was used for solid-liquid separation. Settling was done at $85^{\circ} \mathrm{C}$.

Lumetta et al. had run a similar process on 15 grams of the Tank 241-C-106 material in screening work leading up to Brooks' larger bench scale test.' In both cases there were two $3 \mathrm{M} \mathrm{NaOH}$ caustic leaches at $100^{\circ} \mathrm{C}$ and three inhibited water washes. Lumetta's data is discussed further in this report, along with the Brooks data that should be the closest match to the Tank 241-C-106 sample analyses reported here.

Ferrara et al. had characterized a portion of the pretreated Tank 241-C-106 sludge slurry produced from the SPD work conducted by Brooks in Part A of the River Protection work. ${ }^{10}$ The characterization was to confirm a more extensive analysis done at Hanford. Major components were similar to those found in the current work except that more sodium was found in Ferrara's work.

The subsamples that had been archived from the products of Brooks' work were listed in a chain-ofcustody. ${ }^{11}$ The subsamples were those that had not been depleted in other testing. Table 1 provides the names of the jars that had been received at SRTC along with the amount of sample removed from each one. All subsample contents from each jar were composited in a single polyethylene carboy and mixed well. Solids from dry jars were slurried up using liquid from other jars as needed to remove as much sample as possible.

Table 1. Envelope D Jars for a Washed Tank C-106 Sample

\begin{tabular}{|l|c|c|c|}
\hline Jar label & $\begin{array}{c}\text { Weight as-received, } \\
\text { grams }\end{array}$ & Weight Empty, grams & Difference, grams \\
\hline C106 1999A & 218.6 & 133.0 & 85.6 \\
\hline C106 1999B & 181.5 & 133.0 & 48.5 \\
\hline C106 FP-AR & 228.9 & 126.0 & 102.9 \\
\hline C106 FP V1-10 & 206.6 & 127.4 & 79.2 \\
\hline C106 FP V1-2 & 183.5 & 129.8 & 53.7 \\
\hline C106 FP V1-4 & 188.2 & 125.3 & 62.9 \\
\hline C106 FP V1-5 & 188.7 & 125.5 & 63.2 \\
\hline C106 FP V1-8 & 194.5 & 129.0 & 65.5 \\
\hline C106 Env. D Product I & 24. & 16.3 & 7.7 \\
\hline Archive dried Product II & 25. & 16.2 & 8.8 \\
\hline Product III & 33.2 & 16.7 & 16.5 \\
\hline TOTAL & & & 594.5 grams \\
\hline
\end{tabular}




\subsection{Analyses}

The SRTC Analytical Development Section (ADS) performed all aqua regia dissolutions, peroxide fusions, weight percent determinations, and further analyses of diluted liquid samples. None of the methods were EPA or SW-846 related. Weight percents were obtained by filtration of known volumes of agitated sample slurry. Solids on the 0.45 -micrion filter disks were dried to constant weight at 105 Celsius. Aqua regia dissolutions are performed on solid samples to provide a liquid whose metal and isotope content represent elemental levels in the solid. Peroxide fusion samples provide representative levels of amphiprotic elements that do not remain soluble in acid solution. Silicon is the main element of interest for peroxide fusion. The following analyses were performed on liquid from composited sample filtrates and on acid and peroxide fusion samples from solids dissolutions. The details on the sample flow are given in the Discussion Section.

Table 2. List of Analyses

\begin{tabular}{|l|l|}
\hline METHOD & \multicolumn{1}{|c|}{ ANALYTES } \\
\hline ICP-Emission Spectroscopy & $\begin{array}{l}\mathrm{Al}, \mathrm{Ba}, \mathrm{B}, \mathrm{Ca}, \mathrm{Cd}, \mathrm{Cr}, \mathrm{Cu}, \mathrm{Fe}, \mathrm{Li}, \mathrm{Mg}, \mathrm{Mn}, \mathrm{Mo}, \mathrm{Na}, \\
\mathrm{Ni}, \mathrm{P}, \mathrm{Pb}, \mathrm{Si}, \mathrm{Sn}, \mathrm{Sr}, \mathrm{Ti}, \mathrm{Zn}, \mathrm{Zr}\end{array}$ \\
\hline Atomic Absorption & $\mathrm{Na}, \mathrm{K}, \mathrm{Hg}$ \\
\hline Chemcheck & $\mathrm{U}$ \\
\hline Ion-Chromatography-Anions & $\mathrm{Cl}, \mathrm{F}, \mathrm{NO} 2, \mathrm{NO}, \mathrm{PO} 4, \mathrm{SO} 4$, Formate, oxalate \\
\hline Gamma counting & $\mathrm{Cs}-137, \mathrm{Co}-60, \mathrm{Eu}-154$ \\
\hline Beta scintillation & $\mathrm{Sr}-90, \mathrm{Tc}-99$ \\
\hline Alpha TTA & Am-241, Cm-244, Pu-238, Pu-239 \\
\hline ICP-Mass Spectroscopy & Mass 230-246 \\
\hline
\end{tabular}

\subsection{Discussion}

\subsection{Standard Glass}

Good practice for sludge analysis includes testing of the analytical dissolution methods with a solid standard at the time that the unknown sludge sample is analyzed. One of the standard glasses SRTC uses for this purpose is "low-activity reference material" or LRM. ${ }^{12}$ The material had been the subject of extensive round-robin testing among DOE labs to ensure that solids dissolution and analysis methods were consistent. This provides assurance that the methods, especially the dissolutions and sample transfers, are working properly and that results are consistent with past analyses where the standard glass was used. The standard glass is nonradioactive. The standard glass composition (Target wt\%) is shown in the right column of Table 3. Cells with "N/A" were of elements not included in the LRM glass. ${ }^{13}$

A 0.248 gram sample of glass was acid-dissolved with aqua regia. A 0.253 gram sample of glass was fused with sodium peroxide, a caustic solid. The peroxide fusion mass was treated with water after fusion and cooling. The liquid product from each process was diluted and split into two samples (total four samples) for cell exit and analysis. Each sample was further split to speed the analysis by allowing methods to be run in parallel. The net effect was that the acid sample and the peroxide fusion sample 
were completely analyzed in duplicate. The work was done in the Shielded Cells at the same time as sludge solids were processed.

Table 3 shows that peroxide fusion did well for aluminum, silicon, and boron as would be expected. The peroxide method does not report sodium because of the sodium peroxide addition. It did not report zirconium because zirconium crucibles are used. The acid-dissolution method did well for major elements including aluminum, calcium, chromium, iron, sodium, manganese, nickel, and titanium as would be expected for these acid-soluble metals. It did poorly as expected for silicon, which does not have an acid-soluble form when substantial fluoride is not present. It also did poorly for phosphorus. Peroxide fusion got within $30 \%$ of the target phosphorus value and showed much lower variability. Percent variation is defined in Section 3.4.

Table 3. Standard Glass Composition - Elemental Weight Percent

\begin{tabular}{|c|c|c|c|c|c|c|}
\hline Element & $\begin{array}{l}\text { LRM Glass } \\
\text { Aqua-Regia }\end{array}$ & & Element & \begin{tabular}{|l} 
LRM Glass \\
Peroxide-Fus
\end{tabular} & & $\begin{array}{c}\text { Reported } \\
\text { Value }\end{array}$ \\
\hline & \begin{tabular}{|l|} 
Value \\
\end{tabular} & $\%$ Variation & & Value & $\%$ Variation & Target wt \% \\
\hline $\mathrm{Al}$ & 4.73 & 4.5 & $\mathrm{Al}$ & 5.01 & 0.9 & 5.07 \\
\hline $\mathrm{B}$ & 2.14 & 8.2 & B & 2.38 & 0.6 & 2.44 \\
\hline$\overline{\mathrm{Ba}}$ & 0.00 & 107.8 & $\mathrm{Ba}$ & 0.00 & 6.3 & 0.001 \\
\hline $\mathrm{Ca}$ & 0.37 & 1.2 & $\mathrm{Ca}$ & 0.47 & 0.6 & 0.379 \\
\hline$\overline{\mathrm{Cd}}$ & 0.14 & 118.4 & $\mathrm{Cd}$ & 0.14 & 1.0 & 0.464 \\
\hline Co & 0.00 & & Co & 0.02 & 0.9 & N/A \\
\hline $\mathrm{Cr}$ & 0.12 & 3.5 & $\mathrm{Cr}$ & 0.20 & 0.4 & 0.13 \\
\hline $\mathrm{Cu}$ & 0.00 & 46.4 & $\mathrm{Cu}$ & 0.01 & 0.4 & N/A \\
\hline $\mathrm{Fe}$ & 0.96 & 1.0 & $\mathrm{Fe}$ & 1.27 & 0.8 & 0.965 \\
\hline $\mathrm{La}$ & 0.00 & & $\mathrm{La}$ & 0.02 & 1.3 & 0.0137 \\
\hline $\mathrm{Li}$ & 0.00 & & $\mathrm{Li}$ & 0.05 & 0.7 & 0.0526 \\
\hline$\overline{\mathrm{Mg}}$ & 0.06 & 0.1 & $\mathrm{Mg}$ & 0.06 & 0.6 & 0.062 \\
\hline $\mathrm{Mn}$ & 0.06 & 3.9 & $\mathrm{Mn}$ & 0.07 & 0.7 & 0.05 \\
\hline Mo & 0.07 & 43.5 & Mo & 0.07 & 0.2 & 0.0067 \\
\hline $\mathrm{Na}$ & 14.30 & 3.2 & $\mathrm{Na}$ & N/A & & 14.96 \\
\hline $\mathrm{Ni}$ & 0.14 & 1.4 & $\mathrm{Ni}$ & 0.16 & 1.0 & 0.142 \\
\hline $\mathrm{P}$ & 0.08 & 102.8 & $\mathrm{P}$ & 0.31 & 4.1 & 0.24 \\
\hline$\overline{\mathrm{Pb}}$ & 0.09 & 2.1 & $\overline{\mathrm{Pb}}$ & 0.26 & 0.7 & 0.094 \\
\hline$\overline{\mathrm{Si}}$ & 0.80 & 1547.8 & $\mathrm{Si}$ & 24.70 & 0.6 & 25.37 \\
\hline $\mathrm{Sn}$ & 0.00 & & $\mathrm{Sn}$ & 0.38 & 1.8 & N/A \\
\hline $\mathrm{Sr}$ & 0.00 & 47.6 & $\mathrm{Sr}$ & 0.01 & 0.2 & N/A \\
\hline$\overline{\mathrm{Ti}}$ & 0.05 & 9.7 & $\mathrm{Ti}$ & 0.12 & 0.7 & 0.06 \\
\hline $\mathrm{V}$ & 0.00 & & $\mathrm{~V}$ & 0.03 & 0.3 & N/A \\
\hline$\overline{Z n}$ & 0.01 & 46.7 & $\mathrm{Zn}$ & 0.01 & 2.0 & N/A \\
\hline$\overline{\mathrm{Zr}}$ & 0.39 & 39.3 & $\mathrm{Zr}$ & N/A & & 0.6874 \\
\hline
\end{tabular}




\subsection{Initial Sample Compositing and Dilution}

The jars listed in Table 1 in the previous section were all composited into a single carboy and mixed well. The mixture was found to be $12.35+/-0.12 \mathrm{wt} \%$ insoluble solids (duplicate measurements). Since there were plans to ultrafilter this material and since a $5 \mathrm{wt} \%$ feed was desired, the first step after compositing was to add inhibited dilution water (deionized water with $0.01 \mathrm{NaOH}$ ) for the insoluble solids weight percent adjustment. The calculated amount of inhibited water is shown in Table 4 below. Measured solids weight percent after the addition was $5.1+/-1 \mathrm{wt} \%$, verifying that the dilution came very close to the 5\% target. Note that there were only five of the six expected weight percents recorded; a weighing error invalidated the sodium peroxide "A" wt\% measurement. Further information on naming the solids aliquots is in Section 3.3.

Table 4. Dilution and weight percents in the Composite

\begin{tabular}{|c|c|c|c|}
\hline STEP & Density & Total Solids & Insoluble Solids \\
\hline Sample no. 3-140392, 594 grams & $1.10+/-0.01 \mathrm{~g} / \mathrm{ml}$ & $16.25+/-0.08 \mathrm{wt} \%$ & $12.35+/-0.12 \mathrm{wt} \%$ \\
\hline Sample volume calculation & \multicolumn{3}{|c|}{$594 \mathrm{grams} /(1.1 \mathrm{~g} / \mathrm{ml})=540 \mathrm{ml}$ of composite } \\
\hline New volume desired & \multicolumn{3}{|c|}{$540 \mathrm{ml} *(12.35 / 5 \mathrm{wt} \%$ insol. $)=1334 \mathrm{ml}$} \\
\hline Volume $0.01 \mathrm{M} \mathrm{NaOH}$ to add & \multicolumn{3}{|c|}{$1334-540=794 \mathrm{ml}$ inhibited water } \\
\hline Five weight percent measurements & 6.44 & 4.4 & 5.75 \\
\hline Average insoluble weight percent & & $+/-1 \mathrm{wt} \%$ insoluble & lids \\
\hline
\end{tabular}

\subsection{Steps for Sample Analysis}

Figure 1 shows the sample flow and steps taken to complete the characterization after the initial composite and dilution to a calculated level of $5 \mathrm{wt} \%$ insoluble solids were made. The first step was to pipette six 3-ml aliquots from the estimated 5 insoluble solids wt $\%$ composite and to perform insoluble wt $\%$ analysis on each of the six. This created just less than $18 \mathrm{ml}$ of filtrate and six aliquots of solid material. These were dried at 105 Celsius to constant weight to complete the weight percent analyses. The six weight percent measurements were named aqua regia $\mathrm{A}, \mathrm{B}$, and $\mathrm{C}$, plus sodium peroxide $\left(\mathrm{Na}_{2} \mathrm{O}_{2}\right)$ $\mathrm{A}, \mathrm{B}$, and $\mathrm{C}$ as shown in the figure. Each solid aliquot was so named to indicate the type of dissolution and replicate. The letters A, B, and C refer to replicates, but the following numbers 1 or 2 refer to the fact that the samples were then split and sent to two separate groups of analysis tasks.

Three of the solids aliquots were acid-digested in Teflon autoclaves, creating BNF-D016-AqRegia-A,B,C liquid samples. Three were fused with sodium peroxide in zirconium crucibles, creating BNF-D016Na2O2-A,B,C liquid samples. Peroxide fusion samples were taken up with water after the fusions. The three liquid samples created in each case were split into sample bottles for a total of twelve samples to be exited and analyzed by ICP-ES, radiochemical, and wet chemistry methods.

Three milliliter aliquots of the filtrate were diluted in $29 \mathrm{ml}$ of $1 \mathrm{M}$ nitric acid (BNF-D016AqRegia_FiltDilute) or deionized water (BNF-D016-Na2O2_FiltDilute-A and BNF-D016Na22_FiltDilute-B). 


\section{Figure 1. Flowchart for Samples to Come From the Six Wt\% Measurements of Diluted D-2 (C106)}

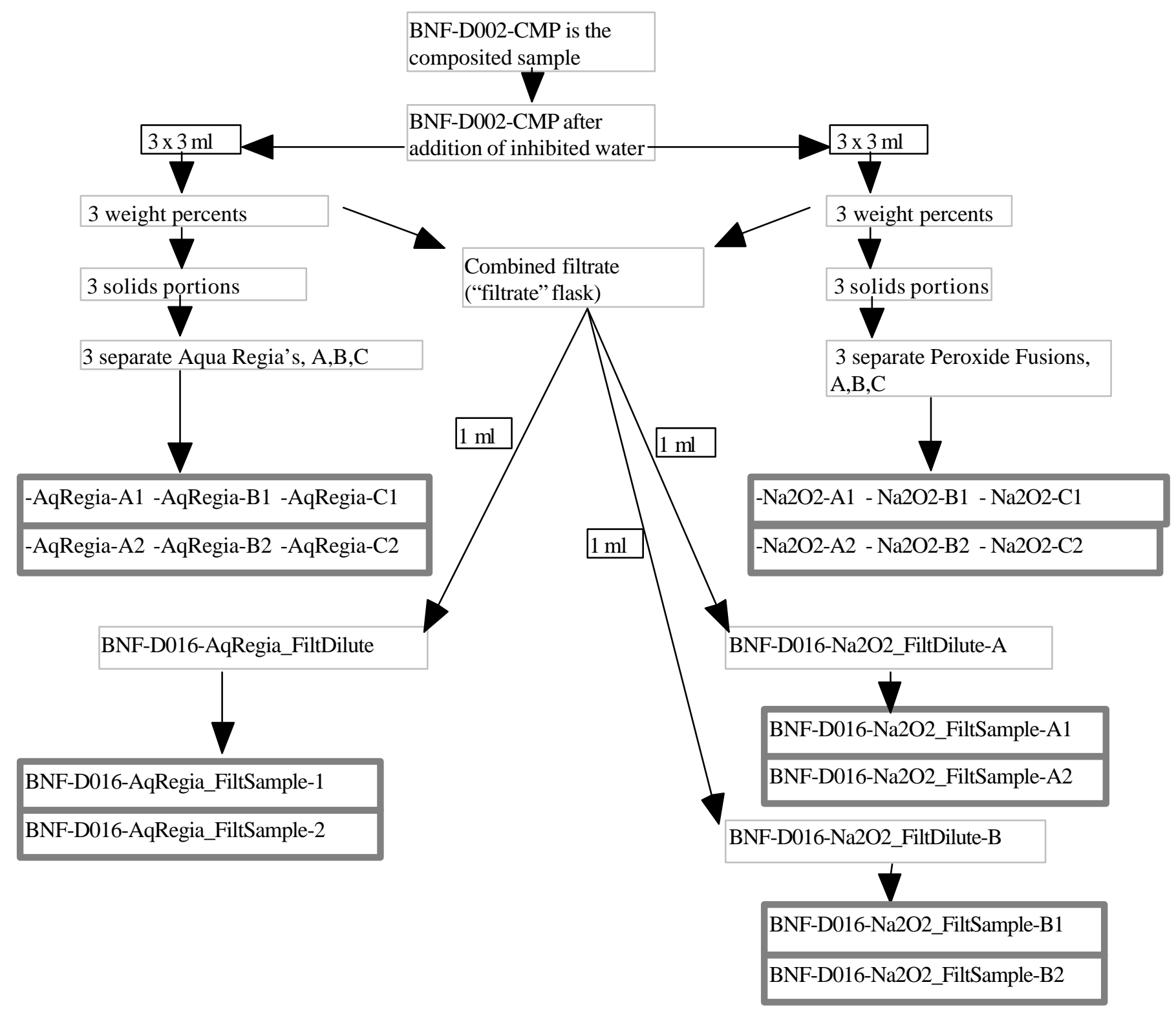

Notes: All filtrate and dissolution sample names began with BNF-D016As-received filtrate was also analyzed.

Boxes with bold borders list diluted samples exited from the Shielded Cells for further analytical work.

Dissolved glass samples are not shown - see text 


\subsection{Filtrate Compositions}

After all jars in Table 1 were composited and mixed well, duplicate filtrate samples were made and diluted by putting $3 \mathrm{ml}$ of filtrate into $29 \mathrm{ml}$ of water (dilution factor 10.67). These were submitted to Analytical to determine the composition of filtrate from as-received material. From Figure 1 these are filtrates from BNF-D002-CMP before bulk dilution. Table 5 below shows the average of each of the two measurements. It also presents a percent variation that is defined as:

Percent Variation $=100 *($ Standard Deviation of the replicate measurements $) /($ Average Value $)$

This definition is used throughout this report.

Table 5. Composition of the Filtrate from the As-Received Composite - ICP-ES Metals

\begin{tabular}{|c|c|c|c|c|}
\hline METALS & & & & \\
\hline ICP-ES & As_Rec'd & & & $\begin{array}{c}\text { Envelope C } \\
\text { Upper Limit }\end{array}$ \\
\hline \multirow[t]{2}{*}{ Element } & Average & Percent & \begin{tabular}{|c|} 
Molar Ratio to $\mathrm{Na}$ \\
(used ICP-ES value)
\end{tabular} & $\begin{array}{c}\text { Molar Ratio to } \\
\mathrm{Na} \\
\end{array}$ \\
\hline & $\mathrm{mg} / \mathrm{liter}$ & variation & & \\
\hline $\mathrm{Al}$ & 28.6 & 1.1 & $3.6 \mathrm{E}-03$ & $2.5 \mathrm{E}-01$ \\
\hline $\mathrm{B}$ & $<0.5$ & Below Det & & \\
\hline $\mathrm{Ba}$ & 2.8 & 3.5 & $7.0 \mathrm{E}-05$ & $1.0 \mathrm{E}-04$ \\
\hline $\mathrm{Ca}$ & 11.5 & 8.9 & $1.0 \mathrm{E}-03$ & 4.0E-02 \\
\hline $\mathrm{Cd}$ & $<0.3$ & Below Det & & $4.0 \mathrm{E}-03$ \\
\hline $\mathrm{Co}$ & $<0.5$ & Below Det & & \\
\hline $\mathrm{Cr}$ & 1.6 & 7.3 & $1.0 \mathrm{E}-04$ & $6.9 \mathrm{E}-03$ \\
\hline $\mathrm{Cu}$ & 0.6 & 29.4 & & \\
\hline $\mathrm{Fe}$ & $<5.7$ & Below Det & & $1.0 \mathrm{E}-02$ \\
\hline $\mathrm{La}$ & $<1.2$ & Below Det & & $8.3 \mathrm{E}-05$ \\
\hline $\mathrm{Li}$ & $<0.2$ & Below Det & & \\
\hline $\mathrm{Mg}$ & $<0.9$ & Below Det & & \\
\hline $\mathrm{Mn}$ & 0.7 & 20.2 & & \\
\hline Mo & $<0.6$ & Below Det & & \\
\hline $\mathrm{Na}$ & 6748.5 & 4.8 & 1.0 & \\
\hline $\mathrm{Ni}$ & 2.6 & 10.3 & $1.5 \mathrm{E}-04$ & $3.0 \mathrm{E}-03$ \\
\hline $\mathrm{P}$ & 328.4 & 12.7 & $3.6 \mathrm{E}-02$ & $\begin{array}{l}3.8 \mathrm{E}-02 \\
\text { (as PO4) }\end{array}$ \\
\hline $\mathrm{Pb}$ & $<3.0$ & Below Det & & $6.8 \mathrm{E}-04$ \\
\hline $\mathrm{Si}$ & 10.3 & 8.7 & $1.3 \mathrm{E}-03$ & \\
\hline $\mathrm{Sn}$ & $<1.6$ & Below Det & & \\
\hline $\mathrm{Sr}$ & 2.7 & 1.7 & $1.0 \mathrm{E}-04$ & \\
\hline$\overline{\mathrm{Ti}}$ & $<0.2$ & Below Det & & \\
\hline $\mathrm{V}$ & $<0.3$ & Below Det & & \\
\hline $\mathrm{Zn}$ & 1.3 & 6.3 & $6.8 \mathrm{E}-05$ & \\
\hline $\mathrm{Zr}$ & 0.8 & 51.8 & $3.0 \mathrm{E}-05$ & \\
\hline
\end{tabular}


Table 6. Composition of the Filtrate from the As-Received Composite - Radiochemistry, Metals, and Anions

\begin{tabular}{|c|c|c|c|c|c|}
\hline \multirow{2}{*}{$\begin{array}{l}\text { RADIO- } \\
\text { CHEMISTRY }\end{array}$} & & $\begin{array}{c}\text { Envelope C } \\
\text { Limit }\end{array}$ & Average & Average & Percent \\
\hline & $\mathrm{Bq} /$ Mole Na & $\mathrm{Bq} /$ Mole Na & dpm/ml & $\mathrm{uCi} / \mathrm{ml}$ & variation \\
\hline $\mathrm{Sr}-90$ & $4.1 \mathrm{E}+06$ & $8.0 \mathrm{E}+08$ & $2.43 \mathrm{E}+05$ & 0.11 & 5.0 \\
\hline $\mathrm{Pu}-238$ & & & $1.84 \mathrm{E}+03$ & 0.00083 & 2.1 \\
\hline $\mathrm{Pu}-239$ & $2.4 \mathrm{E}+04$ & & $4.24 \mathrm{E}+02$ & 0.00019 & 60.8 \\
\hline $\mathrm{Tc}-99$ & & $7.1 \mathrm{E}+06$ & $<2.2 \mathrm{E}+03$ & $<0.001$ & Below Det \\
\hline $\mathrm{Am}-241$ & $6.1 \mathrm{E}+05$ & $\begin{array}{c}3.0 \mathrm{E}+06 \\
(\mathrm{TRU})\end{array}$ & $1.07 \mathrm{E}+04$ & 0.00480 & \\
\hline $\mathrm{Cs}-137$ & $2.2 \mathrm{E}+08$ & $4.3 \mathrm{E}+09$ & $3.90 \mathrm{E}+06$ & 1.76 & 4.8 \\
\hline
\end{tabular}

\begin{tabular}{|c|c|c|c|c|c|}
\hline $\begin{array}{l}\text { METALS by } \\
\text { Atomic } \\
\text { Absorption }\end{array}$ & \multicolumn{1}{|l|}{} \\
\hline Atom. $\mathrm{Ab}$. & $\begin{array}{c}\text { Molar Ratio to } \\
\mathrm{Na}\end{array}$ & $\begin{array}{c}\text { Molar Ratio to } \\
\mathrm{Na}\end{array}$ & & & \\
\hline $\mathrm{Hg}$ & $5.2 \mathrm{E}-06$ & $1.4 \mathrm{E}-05$ & 0.307 & $\mathrm{mg} / \mathrm{liter}$ & 6.1 \\
\hline $\mathrm{U}$ & $3.3 \mathrm{E}-03$ & $1.2 \mathrm{E}-03$ & 232 & $\mathrm{mg} / \mathrm{liter}$ & 4.9 \\
\hline $\mathrm{K}$ & & $1.8 \mathrm{E}-01$ & $<4$ & $\mathrm{mg} / \mathrm{liter}$ & Below Det \\
\hline
\end{tabular}

\begin{tabular}{|c|c|c|c|c|c|}
\hline ANIONS & & & & & \\
\hline IC-anions & $\begin{array}{l}\text { Molar Ratio to } \\
\mathrm{Na}\end{array}$ & $\begin{array}{c}\text { Molar Ratio to } \\
\mathrm{Na}\end{array}$ & $\begin{array}{l}\text { Average } \\
\mathrm{mg} / \text { liter }\end{array}$ & $\begin{array}{l}\text { Percent } \\
\text { Variation }\end{array}$ & Molarity \\
\hline Chloride* $^{*}$ & $3.46 \mathrm{E}-01$ & $3.7 \mathrm{E}-02$ & $3600^{*}$ & 0.2 & $0.102 *$ \\
\hline Fluoride & & $9.1 \mathrm{E}-02$ & $<213$ & Below Det & \\
\hline Formate & & & $<1067$ & Below Det & \\
\hline Nitrate & $2.24 \mathrm{E}-01$ & $8.0 \mathrm{E}-01$ & 4075 & 0.4 & 0.0657 \\
\hline Nitrite & $4.2 \mathrm{E}-02$ & $3.8 \mathrm{E}-01$ & 565 & 0.0 & 0.0123 \\
\hline Oxalate & $\begin{array}{l}7.26 \mathrm{E}-01 \\
\text { (as TOC) } \\
\end{array}$ & $\begin{array}{c}5.0 \mathrm{E}-01 \\
\text { (as TOC) }\end{array}$ & 9355 & 1.5 & 0.105 \\
\hline PO4 & & $3.8 \mathrm{E}-02$ & $<1067$ & Below Det & \\
\hline Sulfate & & $2.0 \mathrm{E}-02$ & $<534$ & Below Det & \\
\hline Na by AA & & & 6312 & 0.7 & 0.274 \\
\hline
\end{tabular}

* Chloride as measured is probably in error - much too high - see text

It is interesting to note that there is significant oxalate among the identified anions. There is no variation shown on the Am-241 because only one value was available for that sample.

The composition of the filtrate present in the as-received Tank 241-C-106 sample complies with the LowActivity Waste (LAW) Envelope C specification for feed to the RPP-WTP ${ }^{14}$, with the exception of 
uranium, chloride, and total organic carbon (TOC). The TOC concentration of the filtrate (primarily oxalate) exceeds the LAW feed limit by $\sim 45 \%$. The uranium concentration of the filtrate exceeds the LAW feed limit by a factor of $\sim 2.75$. The chloride concentration of the filtrate is almost ten times that of the LAW feed limit, however, comparison with other work shows that this chloride number is probably in error. Both Brooks (reference 8) and Lumetta (reference 9) show little chloride in their 241-C-106 samples after leaching. Chloride is below detection in their leachates and leached solids analyses. Furthermore, an analysis of the filtrate by Crawford and Schumacher in an upcoming crucible vitrification report provides more precise chloride measurements in the sample filtrate. Chloride was found to be less than $10 \mathrm{mg} / \mathrm{liter}{ }^{15}$ In comparison with the LAW Envelope A feed limits, the filtrate present with the Tank 241-C-106 sample would exceed the feed limits for uranium, TOC, and transuranic elements.

Table 7 shows the composition of the filtrate after the $794 \mathrm{ml}$ inhibited water addition was made to the initial composite. From Figure 1 these are filtrates from BNF-D016-AqRegia-FiltDilute and BNF-D016Na2O2-FiltDilute-A,B after bulk dilution. Results are the average of three replicates. Each sample had been diluted 1:30 to reduce operator exposure. Many of the metals normally listed in the ICP-ES part of the table were omitted here because they were below detection.

The average sodium level is higher than expected. If the average of the ICP-ES and Atomic Absorption values from the undiluted composite from Tables 5-6 is assumed ( $0.284 \mathrm{M}$ sodium), then the dilution caused by adding $794 \mathrm{ml}$ to $540 \mathrm{ml}$ of sample should result in a new sodium level of $0.12 \mathrm{M}$. The fact that the sodium level as-found here is $0.167 \mathrm{M}$ suggests that additional sodium dissolved out of the solids. This is also plausible from the comparison of these results to the comparison with other work - see Section 3.6. Oxalate is also somewhat higher than expected from simple dilution suggesting that some of the sodium involved in additional dissolution might be sodium oxalate.

Table 7. Composition of the Filtrate from the Diluted Composite

\begin{tabular}{|l|l|l|}
\hline Metals & \multicolumn{2}{|l|}{} \\
\hline ICP-ES & Dilute & \\
\hline Element & Average & Percent \\
\hline & $\mathrm{mg} /$ liter & Variation \\
\hline $\mathrm{Mg}$ & 1.0 & 10.2 \\
\hline $\mathrm{Na}$ & 3844.0 & 2.9 \\
\hline $\mathrm{P}$ & 146.1 & 5.7 \\
\hline $\mathrm{Zn}$ & 1.0 & 6.2 \\
\hline
\end{tabular}

\begin{tabular}{|l|c|l|l|}
\hline Anions \\
\hline IC Anions & Average & Percent & \\
\cline { 2 - 5 } & $\mathrm{mg} /$ liter & Variation & Molarity \\
\hline Chloride & $<600$ & Below Det & \\
\hline Fluoride & $<600$ & Below Det & \\
\hline Formate & $<3000$ & Below Det & \\
\hline Nitrate & $<3000$ & Below Det & \\
\hline Nitrite & $<3000$ & Below Det & \\
\hline Oxalate & 4500 & 1.0 & 0.051 \\
\hline PO4 & $<3000$ & Below Det & \\
\hline Sulfate & $<1500$ & Below Det & \\
\hline
\end{tabular}

\begin{tabular}{|l|c|c|c|}
\hline \multicolumn{2}{|l|}{ Radiochemical } & \multicolumn{2}{l}{} \\
\cline { 1 - 2 } & $\begin{array}{l}\text { Average } \\
\text { dpm/ml }\end{array}$ & $\begin{array}{l}\text { Average } \\
\text { uCi/ml }\end{array}$ & $\begin{array}{l}\text { Percent } \\
\text { Variation }\end{array}$ \\
\hline Sr-90 & $1.39 \mathrm{E}+05$ & 0.063 & 24 \\
\hline Pu-238 & $8.54 \mathrm{E}+04$ & 0.038 & 56 \\
\hline Pu-239 & $2.13 \mathrm{E}+03$ & 0.001 & 62 \\
\hline Tc-99 & $<5 . \mathrm{E}+03$ & & Below Det \\
\hline Am-241 & $4.37 \mathrm{E}+03$ & 0.002 & 36 \\
\hline Cs-137 & $8.35 \mathrm{E}+05$ & 0.38 & 22 \\
\hline
\end{tabular}

\begin{tabular}{|l|c|c|c|}
\hline \multicolumn{3}{|l|}{ Atomic Absorption } & \multicolumn{1}{l}{} \\
\hline $\mathrm{Hg}$ & 0.132 & $\mathrm{mg} /$ liter & 66.1 \\
\hline $\mathrm{U}$ & 96.900 & $\mathrm{mg} /$ liter & 19.4 \\
\hline $\mathrm{K}$ & $<10$ & $\mathrm{mg} /$ liter & \\
\hline
\end{tabular}




\subsection{Solids Composition}

The six solid samples, three that had been acid-dissolved (BNF-D016-AqRegia A,B,C) and three that had been sodium peroxide fused (BNF-D016-Na2O2-A,B,C), were analyzed to provide the data in Tables 8 to 10 below. Table 8 presents the standard deviation of the data that were averaged in each case. It must be noted that while the three acid-dissolved samples appeared to be reasonable that the first peroxide fused replicate BNF-D016-Na2O2-A was found to be below detection levels on all items and was not used in the peroxide average. It is suspected that the sample was not diluted properly.

Table 8. Composition of the Dried Solid Sludge

\begin{tabular}{|c|c|c|c|c|c|c|c|}
\hline Element & $\begin{array}{c}\text { Overall } \\
\text { Average } \\
\mathrm{Wt} \%\end{array}$ & $\begin{array}{l}\text { Standard } \\
\text { Deviation }\end{array}$ & $\begin{array}{l}\text { Methods included } \\
\text { in average }\end{array}$ & Oxide & $\begin{array}{l}\text { Oxide } \\
\text { M.W. } \\
\text { Grams }\end{array}$ & $\begin{array}{c}\text { Grams /100 Grams } \\
\text { waste Oxide }\end{array}$ & $\begin{array}{c}\text { Envelope D Limit } \\
\text { Gram /100 Gram waste } \\
\text { oxide }\end{array}$ \\
\hline $\mathrm{Al}$ & 5.51 & 1.55 & Aqua Regia plus Peroxide & $\mathrm{Al} 2 \mathrm{O} 3$ & 102 & 9.48 & 14 \\
\hline $\mathrm{B}$ & $<0.02$ & Below Det & & & & & \\
\hline $\mathrm{Ba}$ & 0.08 & 0.02 & Aqua Regia & $\mathrm{BaO}$ & 153.3 & 0.14 & 4.5 \\
\hline $\mathrm{Ca}$ & 0.56 & 0.12 & Aqua Regia plus Peroxide & $\mathrm{CaO}$ & 56 & 0.96 & 7.1 \\
\hline $\mathrm{Cd}$ & $<0.01$ & Below Det & & & & & \\
\hline $\mathrm{Co}$ & $<0.00$ & Below Det & & & & & \\
\hline $\mathrm{Cr}$ & $<0.06$ & Below Det & & & & & \\
\hline $\mathrm{Cu}$ & $<0.02$ & Below Det & & & & & \\
\hline $\mathrm{Fe}$ & 14.10 & 3.58 & Aqua Regia plus Peroxide & $\mathrm{Fe} 2 \mathrm{O} 3$ & 159.7 & 24.25 & 29 \\
\hline $\mathrm{La}$ & $<0.01$ & Below Det & & & & & \\
\hline $\mathrm{Li}$ & $<0.00$ & Below Det & & & & & \\
\hline $\mathrm{Mg}$ & $<0.08$ & Below Det & & & & & \\
\hline $\mathrm{Mn}$ & 0.29 & 0.07 & Aqua Regia plus Peroxide & $\mathrm{MnO} 2$ & 86.9 & 0.5 & 6.5 \\
\hline Mo & $<0.00$ & Below Det & & & & & \\
\hline $\mathrm{Na}$ & 6.10 & 2.33 & Aqua Regia & $\mathrm{Na} 2 \mathrm{O}$ & 62 & 10.5 & 19 \\
\hline $\mathrm{Ni}$ & 0.15 & 0.04 & Aqua Regia plus Peroxide & $\mathrm{NiO}$ & 74.7 & 0.26 & 2.4 \\
\hline $\mathrm{P}$ & 0.34 & 0.04 & Peroxide & $\mathrm{P} 2 \mathrm{O} 5$ & 142 & 0.59 & 1.7 \\
\hline $\mathrm{Pb}$ & 0.40 & 0.14 & Aqua Regia & $\mathrm{PbO}$ & 223.2 & 0.69 & 1.1 \\
\hline $\mathrm{Si}$ & 7.37 & 0.74 & Peroxide & $\mathrm{SiO} 2$ & 60.1 & 12.7 & 19 \\
\hline $\mathrm{Sn}$ & 0.19 & 0.26 & Aqua Regia plus Peroxide & $\mathrm{SnO} 2$ & 150.7 & 0.33 & Not specified \\
\hline $\mathrm{Sr}$ & $<0.01$ & Below Det & & & & & \\
\hline $\mathrm{Ti}$ & 0.05 & 0.01 & Aqua Regia & $\mathrm{TiO} 2$ & 80 & 0.086 & 1.3 \\
\hline $\mathrm{V}$ & $<0.00$ & Below Det & & & & & \\
\hline $\mathrm{Zn}$ & $<0.01$ & Below Det & & & & & \\
\hline $\mathrm{Zr}$ & 0.31 & 0.06 & Aqua Regia & $\mathrm{ZrO} 2$ & 123.2 & 0.53 & 15 \\
\hline $\begin{array}{c}\text { Grams waste } \\
\text { oxide per } \\
\text { gram solids }\end{array}$ & 0.58 & & & & & & \\
\hline
\end{tabular}


Tables A-1 through A-4 in the Appendix show the raw data used for the aqua regia and peroxide fusion averages. Elemental levels in each liquid sample created from each of the six dissolutions are different from each other because the sample masses were different in each case. For instance, BNF-D016AqRega-B has elemental levels 2 to 3 times higher than that of sample BNF-D016-AqRega-A, but the recorded mass for the B solids was $0.194 \mathrm{~g}$ versus $0.121 \mathrm{~g}$ for BNF-D016-AqRega-A. Sample masses are found at the bottom of Table A-1 and within Table A-4.

The choice of which of the two methods to use for reporting each nonradioactive element was made by guidance from the standard glass dissolution work along with comparison of results between the two methods. Silicon from peroxide fusion alone was used as expected, and phosphorus had also been found to be taken up well by this method alone. Metals were well measured by the acid dissolution method as expected. Alpha emitters came from cells contamination and are not part of the comparison. The composition of the unwashed Tank 241-C-106 solids (shown in last column of Table 8) is compliant with the HLW feed specification for the RPP-WTP. ${ }^{16}$

Tables 9 and 10 show the radiochemical results for each dissolution method. Results overall compare well with other work as shown in the next section, but $\mathrm{Pu}-238$ by the peroxide fusion method is anomalously high, possibly because of an error in one of the two available measurements.

ICP-MS reported that mass 235 is 0.4 to 0.7 percent of the mass 238 value, indicating uranium in its natural isotopic ratio, within the large error. There was also detectable mass 232 indicating thorium.

Curium-244 is reported though most of it was likely picked up in the cells during the current characterization. The standard glass samples (initially non-radioactive) processed in the cells picked up approximately $0.1 \mathrm{uCi} / \mathrm{g}$ of $\mathrm{Am}-241$ and between 0.5 to $1.5 \mathrm{uCi} / \mathrm{g} \mathrm{Cm}-244$. Lumetta reported $0.15 \mathrm{uCi} / \mathrm{g}$ Cm-243/244 in his caustic leaching work. ${ }^{9}$

Table 9. Radiochemical Composition of the Dried Solids by Acid Dissolution

\begin{tabular}{|l|l|c|c|}
\hline & $\begin{array}{l}\text { Average } \\
\text { dpm/g }\end{array}$ & $\begin{array}{l}\text { Average } \\
\text { uCi/g }\end{array}$ & $\begin{array}{l}\text { Percent } \\
\text { Variation }\end{array}$ \\
\hline Cs-137 & $1.07 \mathrm{E}+09$ & 481.37 & 34 \\
\hline Eu-154 & $6.21 \mathrm{E}+06$ & 2.80 & 28 \\
\hline Eu-155* & & & \\
\hline Co-60* & & & \\
\hline Am-241 & $7.29 \mathrm{E}+06$ & 3.28 & 33 \\
\hline Cm-244 & $1.32 \mathrm{E}+06$ & 0.60 & 7 \\
\hline Pu-239 & $5.99 \mathrm{E}+06$ & 2.70 & 53 \\
\hline Pu-238 & $1.77 \mathrm{E}+06$ & 0.80 & 8 \\
\hline \multicolumn{4}{|c|}{} \\
\hline Tc-99 & $4.36 \mathrm{E}+05$ & 0.20 & 44 \\
\hline Sr-90 & $1.67 \mathrm{E}+09$ & 751.40 & 32 \\
\hline Total U & $1.57 \mathrm{E}+03$ & $\mathrm{ug} / \mathrm{g}$ & 42 \\
\hline Mass 235 & $3.56 \mathrm{E}+00$ & $\mathrm{ug} / \mathrm{g}$ & 87 \\
\hline Mass 238 & $9.43 \mathrm{E}+02$ & $\mathrm{ug} / \mathrm{g}$ & 67 \\
\hline Mass 239 & $2.62 \mathrm{E}+01$ & $\mathrm{ug} / \mathrm{g}$ & 58 \\
\hline Mass 232 & $6.43 \mathrm{E}+02$ & $\mathrm{ug} / \mathrm{g}$ & 40 \\
\hline \multicolumn{4}{|c}{${ }^{*}$ Below Detection in all cases } \\
\hline
\end{tabular}


Table 10. Radiochemical Composition of the Dried Solids by Sodium Peroxide Fusion

\begin{tabular}{|l|c|c|c|}
\hline & $\begin{array}{l}\text { Average } \\
\text { dpm/g }\end{array}$ & $\begin{array}{l}\text { Average } \\
\text { uCi/g }\end{array}$ & $\begin{array}{l}\text { Percent } \\
\text { Variation }\end{array}$ \\
\hline Cs-137 & $9.03 \mathrm{E}+08$ & 406.60 & 19 \\
\hline Eu-154 & $4.84 \mathrm{E}+06$ & 2.18 & 1 \\
\hline Eu-155* & & & \\
\hline Co-60* & & & \\
\hline Am-241 & $6.41 \mathrm{E}+06$ & 2.89 & 0 \\
\hline Cm-244** & $2.41 \mathrm{E}+06$ & 1.09 & 19 \\
\hline Pu-239 & $6.22 \mathrm{E}+06$ & 2.80 & 11 \\
\hline Pu-238 & $4.01 \mathrm{E}+07$ & 18 & 114 \\
\hline \multicolumn{4}{|l|}{} \\
\hline Tc-99 & $<6.6 \mathrm{E}+05$ & $<0.3$ & $\begin{array}{c}\text { Below } \\
\text { Det. }\end{array}$ \\
\hline Sr-90 & $1.65 \mathrm{E}+09$ & 743.903 & 20 \\
\hline Total U & $1.13 \mathrm{E}+03$ & $\mathrm{ug} / \mathrm{g}$ & 9 \\
\hline Mass 235 & $1.28 \mathrm{E}+01$ & $\mathrm{ug} / \mathrm{g}$ & 65 \\
\hline Mass 238 & $1.78 \mathrm{E}+03$ & $\mathrm{ug} / \mathrm{g}$ & 63 \\
\hline Mass 239 & $4.37 \mathrm{E}+01$ & $\mathrm{ug} / \mathrm{g}$ & 60 \\
\hline Mass 232 & $5.52 \mathrm{E}+02$ & $\mathrm{ug} / \mathrm{g}$ & 5 \\
\hline $\begin{array}{l}{ }^{*} \text { Below Detection in all cases } \\
\text { ** Probably high due to trace curium } \\
\text { contamination during current analysis }\end{array}$ \\
\hline
\end{tabular}

\subsection{Comparison of Solids Composition to Other Work}

This section compares the bulk elemental and major isotopic analysis of the current work with those of Brooks et al. (reference 8) and Lumetta et al. (reference 9). Figure 2 plots their elemental weight percents versus the current measurements for the solids after filtration from a $5.1 \mathrm{wt} \%$ slurry. Note that weight percent here is on the basis of dried solids, and that oxygen (not measured) will make up a large part of the elemental weight percent for these materials.

It is most notable first that current and past work correlate well on the major elements aluminum, silicon, and iron. Secondly, the current work shows a lower relative sodium level than both of the other works. It is believed that the dilution of the SRS sample to reduce the insoluble weight percent to 5.1 also dissolved up additional sodium.

The slope of the line comparing this work with the Lumetta data show that Lumetta found higher relative levels of all major elements, but that the proportions (good linearity as indicated from the r-squared or correlation coefficient) are the same. Brooks' data showed good proportionality with the current work as shown by the unit slope of the line. The lower correlation coefficient was due almost entirely to the higher sodium level reported by Brooks. The additional washout of sodium in the dilution of the current work is at least partly contributing there. It is similar to a fourth water wash except that the time is greatly extended from the 30 minute processing time that PNNL normally uses for a water wash of sludge. 


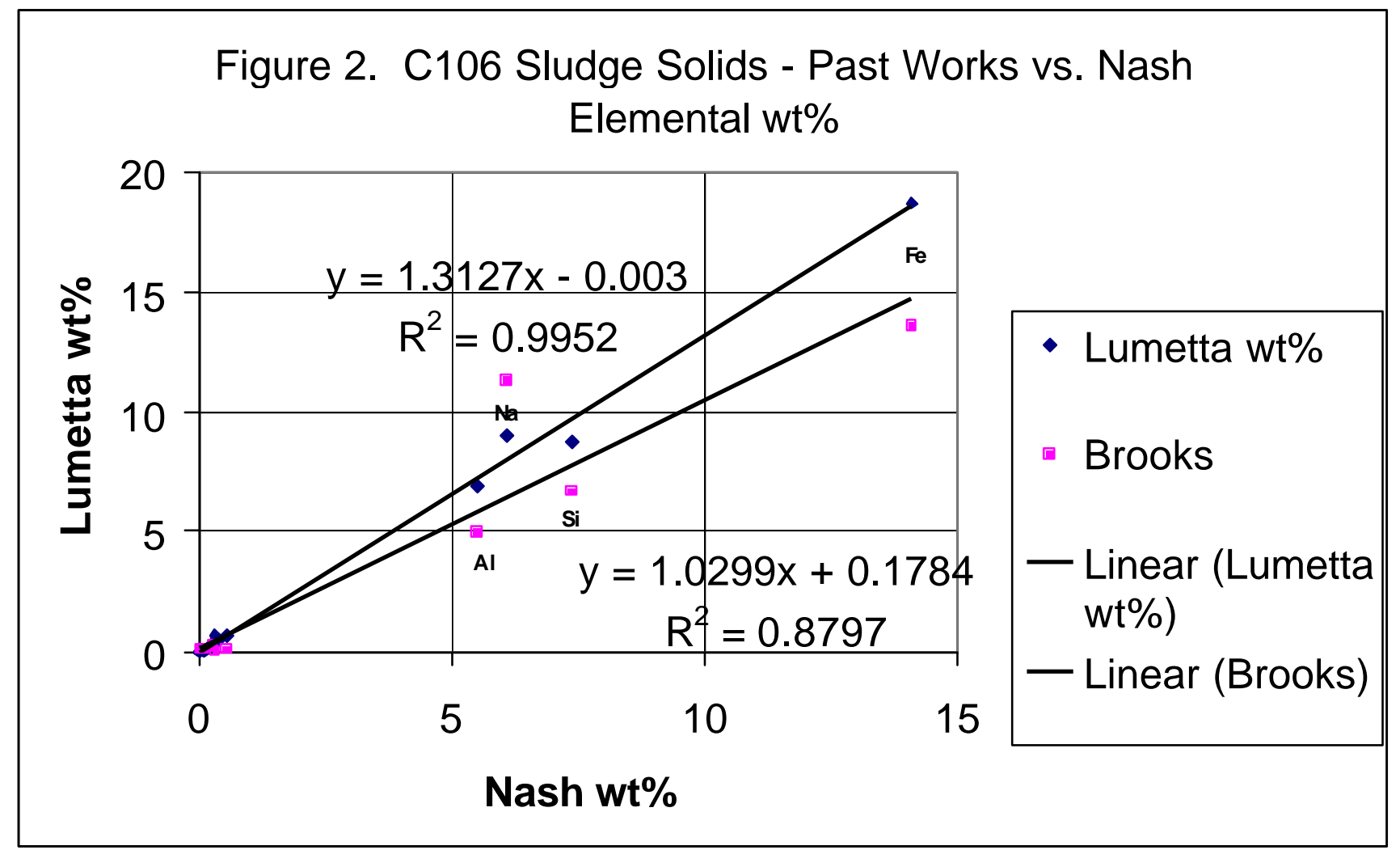

Table 11. Tabular Data for Figure 2.

\begin{tabular}{|c|c|c|c|}
\hline Element & Nash wt\% & Lumetta wt\% & Brooks wt\% \\
\hline $\mathrm{Al}$ & 5.51 & 6.91 & 4.91 \\
\hline $\mathrm{B}$ & 0.02 & & \\
\hline $\mathrm{Ba}$ & 0.08 & 0.06 & \\
\hline $\mathrm{Ca}$ & 0.56 & 0.65 & 0.05 \\
\hline $\mathrm{Cd}$ & 0.01 & 0.01 & \\
\hline $\mathrm{Co}$ & 0.00 & & 0.07 \\
\hline $\mathrm{Cr}$ & 0.06 & 0.01 & \\
\hline $\mathrm{Cu}$ & 0.02 & & 13.60 \\
\hline $\mathrm{Fe}$ & 14.10 & 18.70 & \\
\hline $\mathrm{La}$ & 0.01 & 0.02 & \\
\hline $\mathrm{Li}$ & 0.00 & & 0.29 \\
\hline $\mathrm{Mg}$ & 0.08 & & \\
\hline $\mathrm{Mn}$ & 0.29 & 0.42 & \\
\hline $\mathrm{Mo}$ & 0.00 & & \\
\hline $\mathrm{Na}$ & 6.10 & 8.97 & \\
\hline $\mathrm{Ni}$ & 0.15 & 0.20 & \\
\hline $\mathrm{P}$ & 0.34 & & \\
\hline & & & \\
\hline
\end{tabular}


Table 11. Tabular Data for Figure 2 - Continued

\begin{tabular}{|c|c|c|c|}
\hline Element & Nash wt\% & Lumetta wt\% & Brooks wt\% \\
\hline $\mathrm{Pb}$ & 0.40 & 0.51 & \\
\hline $\mathrm{Si}$ & 7.37 & 8.74 & 6.66 \\
\hline $\mathrm{Sn}$ & 0.19 & & \\
\hline $\mathrm{Sr}$ & 0.01 & 0.00 & \\
\hline $\mathrm{Ti}$ & 0.05 & 0.08 & 0.10 \\
\hline $\mathrm{V}$ & 0.00 & & \\
\hline $\mathrm{Zn}$ & 0.01 & & 0.01 \\
\hline $\mathrm{Zr}$ & 0.31 & 0.62 & \\
\hline
\end{tabular}

Levels of the major radionuclides Sr-90, Cs-137, and Eu-154 compare well between the current work and that of Brooks as seen in Table 12. Cs-137 by acid dissolution appears to be more reliable than that of peroxide fusion. It is perhaps aided by the fact that three useful samples were available for the acid side work while one of the peroxide fusion samples could not be used. Tc-99 was at or near detection in the current work so it is not possible to make a direct comparison with Brooks' Tc-99 data.

Table 12. Comparison of Major Isotopic Levels with Brooks (ref. 8)

\begin{tabular}{|c|c|c|c|}
\hline Isotope & $\begin{array}{c}\text { This Work - } \\
\text { Acid Dissolution }\end{array}$ & $\begin{array}{c}\text { This Work - } \\
\text { Peroxide Fusion }\end{array}$ & Brooks' Work \\
\hline Sr-90 & 751 & 744 & 730 \\
\hline Cs-137 & 481 & 407 & 495 \\
\hline Eu-154 & 2.8 & 2.2 & 3.8 \\
\hline Tc-99 & 0.2 & $<0.3$ & 0.0056 \\
\hline \multicolumn{4}{|r}{ All entries are in microCuries per gram of solids } \\
\hline
\end{tabular}

\subsection{Conclusion/Summary}

This work confirmed that the SRTC C106 sample analysis compared well with the closest past analysis, that is, the Sludge Pretreatment Demonstration (SPD) by Brooks and co-workers. Both bulk elemental and major isotopic levels compared well. Some additional sodium was found to wash out during dilution of the sample. Other measured constituents appeared to remain with their respective liquid or solid phases during the dilution so that the solids analyses compared well with Brooks overall. Chloride as measured in this characterization of the filtrate from the as-received sample is strongly suspected to be too high because of comparisons with past work. The true chloride level in 241-C-106 samples after leaching is probably below detection in all cases. 


\subsection{References}

1 Wach, S. T., "RPP Privatization Part B, SRTC WFO-98-003, Submittal Of AZ-102 Solids Calculation, Correspondence no. BNF-003-98-0126, to Michael E. Johnson, July 16, 1999.

2 Johnson, M. E., "Contract No. DE-AC06-96RL13308-W375- C-106 to Replace AZ-102 Solids for High-Level Waste Tests”, Correspondence no. 005554, Recipient Steve Wach, August 19, 1999.

3 Hay, M. S., "Task Technical and Quality Assurance Plan for Sample Characterization and Sludge Washing in Support of BNFL Part B”, BNF-003-98-0013, rev. 0, October 21, 1998.

4 SRTC Laboratory notebook WSRC-NB-2000-00104.

5 Kuhl-Klinger, K. J. "Tank Waste Remediation System (TWRS) Privatization Contractor Samples, Waste Envelope D Material - 241-C-106 Analytical Summary Report”, Pacific Northwest National Laboratory, Richland, WA, October 7, 1996

6 Schreiber, R. D., "Tank 241-C-106 Grab Sampling and Analysis Plan”, WHC-SD-WM-TSAP-080, rev. 0, Westinghouse Hanford Company, Richland, WA, 1996.

7 Urie, M. W., “Tank Waste Remediation System (TWRS) Privatization Contractor Samples, Waste Envelope D Material - 241-C-106 Analytical Summary Report”, Pacific Northwest National Laboratory, Richland, WA, January 28,1997

8 Brooks, K. P., Myers, R. L., and Rappe, K. G., "Bench-Scale Enhanced Sludge Washing and Gravity Settling of Hanford Tank C-106 Sludge”, PNNL-11432, rev. 0, Pacific Northwest National Laboratory, Richland, WA, 1996.

9 Lumetta, G. J., Hoopes, F. V., Wagner, M. J., and Steele, R. T., "Washing and Caustic Leaching of Hanford Tank C-106 Sludge”, PNNL-11381, rev. 0, Pacific Northwest National Laboratory, Richland, WA, Oct. 1996.

10 Ferrara, D. M., Bibler, N. E., Crawford, C. L., and Ha, B. C., "Westinghouse Savannah River Company Analytical Report for Waste Envelope D Sample (U)”, SRTC-BNFL-009, rev. 0, Nov. 20, 1997.

${ }^{11}$ Thornhill, R. E., and Urie, M. W., RPG External Chain-of-Custody, number 325.RPG.14

12 Ebert, W. L., and Wolfe, S. F., "Round-Robin Testing of a Reference Glass for Low-Activiity Waste Forms", ANL-99/22, Argonne National Laboratory, October 1999.

13 Peeler, D. K., Cozzi, A. D., Best, D. R., Coleman, C. J., and Reamer, I. A., "Characterization of the Low Level Waste Reference Glass (LRM), WSRC-TR-99-00095, rev. 0, March 30, 1999.

14 Specification 7: Low Activity Waste Envelopes Definition, Contract No. DE-AC27-01RV14136, U. S. Department of Energy Office of River Protection, December 2000.

15 Personal communications with Charles Crawford and Ray Schumacher, 03/22/2001.

16 Specification 8: High Activity Waste Envelopes Definition, Contract No. DE-AC27-01RV14136, U. S. Department of Energy Office of River Protection, December 2000. 


\section{APPENDIX}

\section{RAW DATA FROM THE CHARACTERIZATION OF C106 SLUDGE (ENVELOPE D)}

Basic information on the samples and analysis tables is listed in this appendix. The following analyses were used in the program:

- ICP-ES: Inductively-Coupled Plasma Emission Spectroscopy provides over a dozen elements, mostly metals.

- $\mathrm{AA}($ element): Atomic Absorption measures (element) concentration.

- Gamma: Gamma counting measures Cs-137, Eu-154, Eu-155, Co-60.

- $\quad \mathrm{Sr}-90$ was measured by a counting method.

- Am-241, plutonium, and curium were measured by a TTA counting technique. A related series of procedures for the same sample provides these.

- IC Anions: Ion Chromatography for common anions

- Tc-99 was measured by beta counting.

- Uranium was measured by a wet chemical method commonly called "Chemcheck".

- Weight percents were measured with standard filtration, drying, and weighing methods.

- Concentrations of mass 230-246 were measured by ICP-Mass Spec.

Note that all tables show Analytical sample numbers. All of these 3-digit numbers are the last three digits of a full SRTC Analytical number 300140xxx where xxx are the three digits of the specific sample. 
Table A-1. ICP-ES Data Shown in Milligrams Per Liter after Sample Dilution

\begin{tabular}{|c|c|c|c|c|c|c|c|c|}
\hline & Filtrate & Filtrate & & & & AqRegia & Standard & Standard \\
\hline & As_Red\#1 & As_Red\#2 & AqReg A & AqReg B & AqReg C & FiltDilute & Glass-1 & Glass-2 \\
\hline ADS\# > & $530-1$ & $\mid 530-2$ & 531 & 532 & 533 & 534 & 535 & 536 \\
\hline & \multicolumn{8}{|c|}{ All units per element are $\mathrm{mg} /$ /iter } \\
\hline $\mathrm{Al}$ & 2.66 & 2.702 & 45.202 & 151.381 & $\begin{array}{r}67.22 \\
\end{array}$ & \begin{tabular}{|l|}
0.536 \\
\end{tabular} & 119.3 & 115.102 \\
\hline$B$ & 0.05 & 0.050 & $<0.05$ & $<0.05$ & $<0.05$ & $<0.05$ & 54.061 & 51.865 \\
\hline $\mathrm{Ba}$ & 0.259 & 0.272 & 1.045 & 1.744 & 0.838 & $<0.02$ & 0.023 & $<0.02$ \\
\hline $\mathrm{Ca}$ & 1.014 & 1.151 & 4.846 & 13.354 & 6.465 & 0.858 & 9.275 & 9.18 \\
\hline $\mathrm{Cd}$ & 0.03 & 0.030 & 0.094 & 0.326 & 0.145 & 0.03 & 3.488 & 3.379 \\
\hline Co & 0.05 & 0.050 & $<0.05$ & 0.098 & $<0.05$ & $<0.05$ & $<0.05$ & $<0.05$ \\
\hline $\mathrm{Cr}$ & 0.162 & 0.146 & 0.616 & 1.674 & 0.76 & $<0.07$ & 3.12 & 3.01 \\
\hline $\mathrm{Cu}$ & 0.064 & 0.042 & 0.14 & 0.447 & 0.195 & $<0.03$ & 0.126 & 0.109 \\
\hline $\mathrm{Fe}$ & 0.536 & 0.535 & 127.333 & 389.835 & 178.194 & 0.345 & 24.317 & 23.464 \\
\hline $\mathrm{La}$ & 0.11 & 0.110 & $<0.11$ & 0.37 & $<0.11$ & $<0.11$ & 0.203 & 0.133 \\
\hline $\mathrm{Li}$ & 0.02 & 0.020 & $<0.02$ & 0.043 & $<0.02$ & $<0.02$ & 1.085 & 1.043 \\
\hline $\mathrm{Mg}$ & 0.088 & 0.089 & 0.82 & 1.929 & 0.864 & 0.038 & 1.584 & 1.535 \\
\hline $\mathrm{Mn}$ & 0.08 & 0.060 & 2.546 & 7.937 & 3.65 & $<0.01$ & 1.404 & 1.346 \\
\hline Mo & 0.06 & 0.060 & $<0.06$ & 0.146 & 0.07 & $<0.06$ & 1.698 & 1.602 \\
\hline $\mathrm{Na}$ & 654.172 & 611.167 & 49.931 & 168.326 & 74.186 & 128.864 & 360.856 & 348.575 \\
\hline $\mathrm{Ni}$ & 0.266 & 0.230 & 1.279 & 3.861 & 1.772 & $<0.07$ & 3.608 & 3.421 \\
\hline$P$ & 33.559 & 28.021 & 2.645 & 3.068 & 2.879 & 4.789 & 2.192 & 1.824 \\
\hline $\mathrm{Pb}$ & 0.28 & 0.280 & 3.345 & 10.747 & 4.938 & $<0.28$ & 2.375 & 2.236 \\
\hline $\mathrm{Si}$ & 1.023 & 0.905 & 9.762 & 10.935 & 10.013 & 0.46 & 24.269 & 15.386 \\
\hline Sn & 0.15 & 0.150 & $<0.15$ & 0.375 & 0.164 & $<0.15$ & $<0.15$ & $<0.15$ \\
\hline $\mathrm{Sr}$ & 0.253 & 0.247 & 0.143 & 0.264 & 0.123 & $<0.01$ & 0.044 & 0.04 \\
\hline $\mathrm{Ti}$ & 0.02 & 0.020 & 0.486 & 1.224 & 0.56 & $<0.02$ & 1.325 & 1.24 \\
\hline $\mathrm{V}$ & 0.03 & 0.030 & 0.035 & 0.094 & 0.033 & $<0.03$ & 0.04 & $<0.03$ \\
\hline $\mathrm{Zn}$ & 0.129 & 0.118 & 0.149 & 0.345 & 0.194 & 0.033 & $\begin{array}{l}0.139 \\
\end{array}$ & 0.122 \\
\hline$Z r$ & 0.045 & 0.097 & 3.049 & 5.91 & 4.978 & $<0.04$ & 10.045 & 9.41 \\
\hline & & & & & & & & \\
\hline g solids & & & 0.121 & 0.194 & 0.135 & & 0.248 & 0.248 \\
\hline liters & & & 0.1 & 0.1 & 0.1 & & 0.1 & 0.1 \\
\hline & & & & & & & & \\
\hline
\end{tabular}


Table A-2. Isotopic Activity and Mass Data after Sample Dilution

\begin{tabular}{|c|c|c|c|c|c|c|c|c|}
\hline & Filtrate & Filtrate & & & & AqRegia & Standard & Standard \\
\hline & As_Red\#1 & $\mid$ As_Red\#2 & AqReg A & AqReg B & AqReg C & FiltDilute & Glass-1 & Glass-2 \\
\hline ADS\# > & $530-1$ & $530-2$ & 531 & 532 & 533 & 534 & 535 & 536 \\
\hline & \multicolumn{8}{|c|}{ All activity units are decays/minute/ml } \\
\hline Cs-137 & $3.54 \mathrm{E}+05$ & $3.79 \mathrm{E}+05$ & $9.22 \mathrm{E}+05$ & $2.86 \mathrm{E}+06$ & $1.31 \mathrm{E}+06$ & $3.82 \mathrm{E}+04$ & \begin{tabular}{|l} 
Below \\
Det.
\end{tabular} & $\begin{array}{l}\text { Below } \\
\text { Det. }\end{array}$ \\
\hline Eu-154 & nd & & $6.01 \mathrm{E}+03$ & & $1.01 E+04$ & & & \\
\hline Eu-155 & nd & & & & & & & \\
\hline Co-60 & nd & & & & & & & \\
\hline Am-241 & $1.00 \mathrm{E}+03$ & & $6.28 \mathrm{E}+03$ & $1.93 E+04$ & $9.07 E+03$ & & $<192$ & $4.28 \mathrm{E}+02$ \\
\hline $\mathrm{Cm}-244$ & $1.11 \mathrm{E}+04$ & & $1.51 \mathrm{E}+03$ & $2.75 \mathrm{E}+03$ & $1.76 \mathrm{E}+03$ & & $<1880$ & $2.81 E+03$ \\
\hline Pu-239 & $2.27 E+01$ & $5.69 \mathrm{E}+01$ & $8.30 \mathrm{E}+03$ & $1.68 \mathrm{E}+04$ & $3.32 \mathrm{E}+03$ & $1.02 \mathrm{E}+00$ & $2.54 \mathrm{E}+01$ & $1.29 \mathrm{E}+01$ \\
\hline Pu-238 & $1.75 \mathrm{E}+02$ & $1.70 \mathrm{E}+02$ & $2.33 E+03$ & $3.42 \mathrm{E}+03$ & $2.20 E+03$ & $1.50 \mathrm{E}+02$ & $4.88 \mathrm{E}+02$ & $5.25 \mathrm{E}+02$ \\
\hline Tc-99 & nd & & $<286$ & $1.11 \mathrm{E}+03$ & 404 & bd & & \\
\hline Sr-90 & $2.20 \mathrm{E}+04$ & $2.36 \mathrm{E}+04$ & $1.53 \mathrm{E}+06$ & $4.41 \mathrm{E}+06$ & $1.98 \mathrm{E}+06$ & $5.90 \mathrm{E}+03$ & & \\
\hline Total U & $\mathrm{mg} / \mathrm{liter}$ & & 1.365 & 4.52 & 1.68 & 3.93 & & \\
\hline \multicolumn{2}{|c|}{ Density, $\mathrm{g} / \mathrm{ml}$} & & 1.0645 & 1.004 & 1.023 & & & \\
\hline Mass 235 & ug/liter & & & 10.08 & 7.40 & & & \\
\hline Mass 238 & ug/liter & & 344.525 & 1948.665 & 2080.435 & & & $1.73 E+05$ \\
\hline Mass 239 & ug/liter & & 12.42413 & 53.78767 & 54.85963 & & & $1.13 \mathrm{E}+06$ \\
\hline Mass 232 & ug/liter & & 497.642 & 1782.567 & 808.908 & & & \\
\hline wt \% TSS & & & 3.79 & 6.44 & 4.4 & & & \\
\hline $\begin{array}{l}\text { Average } \\
\%\end{array}$ & & & & 4.877 & & & & \\
\hline \multicolumn{2}{|c|}{ Grand Avg \% } & & & 5.082 & wt $\%$ & 1.052079 & (St. Dev.) & \\
\hline \multicolumn{2}{|c|}{ Grand Avg density } & & & 1.025633 & & 0.022042 & (St. Dev.) & \\
\hline
\end{tabular}

Note: Activities are in $\mathrm{dpm} / \mathrm{ml}$. nd = not detected. 
Table A-3. ICP-ES Data Shown in Milligrams Per Liter after Sample Dilution

\begin{tabular}{|c|c|c|c|c|c|c|c|c|}
\hline & Three & Peroxide & Fusions & & & Below & Standard & Standard \\
\hline & Na2O2-A & Na2O2-B & Na2O2-C & FiltDil_A & FiltDil_B & Detect & Glass-1 & Glass-2 \\
\hline ADS\# > & 544 & 545 & 546 & 547 & 548 & 547,548 & 549 & 550 \\
\hline & \multicolumn{8}{|c|}{ All units per element are $\mathrm{mg} / \mathrm{liter}$} \\
\hline $\mathrm{Al}$ & 15.351 & 93.967 & 85.538 & \begin{tabular}{|r|}
0.72 \\
\end{tabular} & 0.72 & $<$ & 122.996 & 125.272 \\
\hline $\mathrm{B}$ & 0.435 & 0.26 & 0.260 & 0.26 & 0.26 & $<$ & 58.556 & 59.315 \\
\hline $\mathrm{Ba}$ & 0.211 & 1.002 & 1.388 & 0.04 & 0.04 & $<$ & \begin{tabular}{|c|}
0.068 \\
\end{tabular} & 0.06 \\
\hline $\mathrm{Ca}$ & 3.747 & 9.942 & 10.315 & 0.09 & 0.09 & $<$ & 11.688 & 11.84 \\
\hline $\mathrm{Cd}$ & 0.111 & 0.238 & 0.207 & 0.03 & 0.03 & $<$ & 3.468 & 3.536 \\
\hline Co & 0.421 & 0.468 & 0.293 & 0.06 & 0.06 & $<$ & 0.455 & 0.463 \\
\hline $\mathrm{Cr}$ & 2.106 & 2.574 & 1.894 & 0.07 & 0.07 & $<$ & 5.021 & 5.057 \\
\hline $\mathrm{Cu}$ & 0.208 & 0.38 & 0.320 & 0.09 & 0.09 & $<$ & 0.286 & 0.284 \\
\hline $\mathrm{Fe}$ & 41.745 & 211.315 & 224.890 & 0.185 & 0.1 & & 31.222 & 31.711 \\
\hline $\mathrm{La}$ & 0.454 & 0.584 & 0.447 & 0.22 & 0.22 & $<$ & 0.562 & 0.548 \\
\hline $\mathrm{Li}$ & 0.09 & 0.09 & 0.090 & 0.09 & 0.09 & $<$ & 1.142 & 1.158 \\
\hline $\mathrm{Mg}$ & 0.324 & 1.573 & 1.447 & 0.034 & 0.031 & & 1.593 & 1.611 \\
\hline $\mathrm{Mn}$ & 0.927 & 4.519 & 4.829 & 0.02 & 0.02 & $<$ & 1.646 & 1.67 \\
\hline Mo & 0.142 & 0.192 & 0.129 & 0.05 & 0.05 & $<$ & 1.824 & 1.83 \\
\hline $\mathrm{Ni}$ & 0.968 & 2.589 & 2.489 & 0.12 & 0.12 & $<$ & 4.008 & 4.087 \\
\hline $\mathrm{P}$ & 2.09 & 5.584 & 5.580 & 4.642 & 5.176 & & 7.321 & 7.944 \\
\hline $\mathrm{Pb}$ & 5.048 & 9.973 & 8.451 & 0.42 & 0.42 & $<$ & 6.602 & 6.505 \\
\hline $\mathrm{Si}$ & 24.071 & 120.028 & 120.507 & 1.7 & 1.7 & $<$ & 608.657 & 616.328 \\
\hline $\mathrm{Sn}$ & 9.056 & 9.003 & 5.504 & 0.16 & 0.16 & $<$ & 9.225 & 9.554 \\
\hline $\mathrm{Sr}$ & 0.21 & 0.297 & 0.237 & 0.03 & 0.03 & $<$ & 0.233 & 0.234 \\
\hline $\mathrm{Ti}$ & 1.636 & 3.056 & 2.577 & 0.07 & 0.07 & $<$ & 2.92 & 2.96 \\
\hline $\mathrm{V}$ & 0.621 & 0.646 & 0.403 & 0.1 & 0.1 & $<$ & 0.657 & 0.653 \\
\hline $\mathrm{Zn}$ & 0.188 & 0.406 & 0.281 & 0.032 & 0.036 & & 0.226 & 0.217 \\
\hline
\end{tabular}


Table A-4. Isotopic and Mass Data Shown in Milligrams Per Liter after Sample Dilution

\begin{tabular}{|c|c|c|c|c|c|c|}
\hline & & Three & Peroxide & Fusions & Standard & Standard \\
\hline & & Na2O2-A & Na2O2-B & $\mathrm{Na2O2-C}$ & Glass-1 & Glass-2 \\
\hline & ADS\# & 544 & 545 & 546 & 549 & 550 \\
\hline & & & & & & \\
\hline Density & $\mathrm{g} / \mathrm{ml}$ & 1.0343 & 1.007 & 1.021 & & \\
\hline wt solids & $g$ & 0.445 & 0.152 & 0.176 & 0.253 & 0.253 \\
\hline Dil Vol & liters & 0.1 & 0.1 & 0.1 & 0.1 & 0.1 \\
\hline wt \% TSS & & 14.34 & 5.03 & 5.75 & FiltDil A & FiltDil B \\
\hline $\mathrm{dpm} / \mathrm{ml}$ & Cs-137 & $2.35 \mathrm{E}+05$ & 1552300.000 & $1.38 \mathrm{E}+06$ & $2.72 \mathrm{E}+04$ & $2.85 \mathrm{E}+04$ \\
\hline $\mathrm{dpm} / \mathrm{ml}$ & Eu-154 & $1.49 \mathrm{E}+03$ & $7.29 E+03$ & $8.60 \mathrm{E}+03$ & Not det. & Not det. \\
\hline dpm/ml & Eu-155 & $9.82 \mathrm{E}+02$ & & & Not det. & Not det. \\
\hline dpm/ml & Co-60 & $1.80 \mathrm{E}+02$ & & & Not det. & Not det. \\
\hline $\mathrm{dpm} / \mathrm{ml}$ & Am-241 & 2040 & 9720 & $1.13 E+04$ & 128 & 163 \\
\hline dpm/ml & Cm-244 & $4.15 \mathrm{E}+03$ & $4.15 \mathrm{E}+03$ & $3.69 \mathrm{E}+03$ & $8.11 \mathrm{E}+03$ & $5.80 \mathrm{E}+03$ \\
\hline $\mathrm{dpm} / \mathrm{ml}$ & Pu-239 & & $1.02 \mathrm{E}+04$ & $1.01 \mathrm{E}+04$ & 88.9 & 53.1 \\
\hline dpm/ml & Pu-238 & & $1.10 \mathrm{E}+05$ & $1.39 \mathrm{E}+04$ & 2550 & 3140 \\
\hline & & & & & & \\
\hline $\mathrm{dpm} / \mathrm{ml}$ & Tc-99 & $<174$ & $<720$ & $<1190$ & $<5000$ & $<5000$ \\
\hline $\mathrm{dpm} / \mathrm{ml}$ & Sr-90 & $|4.07 \mathrm{E}+05|$ & $2.87 \mathrm{E}+06$ & $2.49 \mathrm{E}+06$ & 3860 & 4180 \\
\hline $\mathrm{mg} /$ liter & Total U & 5.08E-01 & $1.82 \mathrm{E}+00$ & $1.86 \mathrm{E}+00$ & & \\
\hline ug/liter & Mass 235 & 9.39 & 28.29 & 12.24 & & \\
\hline ug/liter & Mass 238 & 1107.355 & 3901.06261 & 1745.931 & & \\
\hline ug/liter & Mass 239 & 24.73586 & 94.4650181 & 44.3497 & & \\
\hline ug/liter & Mass 232 & 139.5189 & 811.236611 & 1001.979 & & \\
\hline
\end{tabular}

TSS datum in the gray box above noted to be unrealistically high 